\title{
Quantification of conformational entropy unravels effect of disor- dered flanking region in coupled folding and binding
}

\author{
Frederik Friis Theisen ${ }^{\dagger \#}$, Lasse Staby ${ }^{\dagger}$, Frederik Grønbæk Tidemand ${ }^{\ddagger}$, Charlotte O’Shea ${ }^{\dagger}$, Andreas
} Prestel $^{\#}$, Martin Willemoës ${ }^{\dagger}$, Birthe B. Kragelund ${ }^{\# * *}$ and Karen Skriver ${ }^{\dagger *}$

'Biomolecular Sciences and "Structural Biology and NMR Laboratory, Department of Biology, University of Copenhagen, Ole Maaloes Vej 5, 2200 Copenhagen N, Denmark

tStructural Biophysics, X-ray and Neutron Science, The Niels Bohr Institute, University of Copenhagen, Universitetsparken 5, 2100 Copenhagen Ø, Denmark

\section{TABLE OF CONTENTS}

Supporting Tables

Table S1: Data used for calculation of surface area coefficients.

Table S2: PDB codes and IDP chain IDs used to determine the ratio between polar and nonpolar surface area burial of IDP interactions.

Table S3: Spolar-Record analysis of previously analyzed interactions.

Table S4: Spolar-Record analysis of ID-based protein-protein interactions with available thermodynamic

Supporting Figures

Figure S1: Fitting of heat capacity changes for solvation of polar and nonpolar surface.

Figure S2: Representative isotherms from ITC experiments conducted with DREB2A $255-272$ over a range of temperatures.

Figure S3: Representative isotherms from ITC experiments conducted with DREB2 $\mathrm{A}_{250-287}$ over a range of temperatures.

Figure S4: Representative isotherms from ITC experiments conducted with DREB2A $243-272$ over a range of temperatures.

Figure S5: Representative isotherms from ITC experiments conducted with DREB2A $234-276$ over a range of temperatures.

Figure S6: NMR analyses of DREB2A $234-276$ interaction with RCD1-RST 499-572.

Figure S7: NMR analyses of the RCD1-RST $499-572$ interaction with DREB2A.

Figure S8: Distribution of ID component chain lengths used for determining ratio of polar to nonpolar surface burial.

Scripts

Script 1: PyMOL script for calculating exposed surface of protein structures. 
Table S1: Data used for calculation of surface area coefficients. Apparent duplicate protein data is either due to different experimental data from multiple groups or slight variation in the length of the protein used. The data has been compiled from a series of papers investigating this relation. Data sources refer to these papers and not the original publications. Duplicate entries with the same experimental source have been merged. Surface area changes are given in $\AA^{2}$ and hydration heat capacity changes are given in $\mathrm{J} \mathrm{mol}^{-1} \mathrm{~K}^{-1}$.

\begin{tabular}{|c|c|c|c|c|c|c|c|}
\hline $\begin{array}{l}\text { Proteins } \\
\text { Arabinose binding protein }{ }^{1}\end{array}$ & $\begin{array}{c}\Delta \boldsymbol{A} S \boldsymbol{A}_{\text {nonpolar }} \\
14847\end{array}$ & $\begin{array}{c}\Delta A S A_{\text {polar }} \\
6539\end{array}$ & $\begin{array}{c}\Delta \boldsymbol{C}_{\mathrm{p}} \\
13200\end{array}$ & $\begin{array}{l}\text { Proteins (continued) } \\
\text { Ribonuclease } T 1^{2}\end{array}$ & $\begin{array}{c}\Delta \boldsymbol{A S A _ { \text { nonpolar } }} \\
5014\end{array}$ & $\begin{array}{c}\Delta A S A_{\text {polar }} \\
3488\end{array}$ & $\begin{array}{l}\Delta C_{\mathrm{p}} \\
5317\end{array}$ \\
\hline Arc repressor ${ }^{1}$ & 5503 & 4633 & 6700 & RNase $T 1^{1,3}$ & 4991.5 & 3301.5 & 5100 \\
\hline Arc repressor $^{2}$ & 6152 & 3080 & 6699 & RNase $T 1^{1}$ & 5049 & 3828 & 4900 \\
\hline B-trypsin ${ }^{4}$ & 11830 & 8495 & 11932 & $\mathrm{ROP}^{2}$ & 7072 & 3174 & 7913 \\
\hline B2 of protein $\mathrm{G}^{1}$ & 2981 & 2117 & 2900 & $\mathrm{ROP}^{1}$ & 9000 & 6737 & 10300 \\
\hline Barnase $^{1}$ & 6190 & 4325 & 5800 & Sac7 $d^{1}$ & 3357 & 2509 & 3600 \\
\hline Barnase $^{1}$ & 6137 & 4281 & 6800 & $\mathrm{SH} 3$ domain of $\alpha$-spectrin ${ }^{1,2}$ & 3361.5 & 1557.5 & 3350 \\
\hline Barnase $^{2}$ & 6706 & 2801 & 6908 & Staphylococcal nuclease ${ }^{2}$ & 8465 & 3593 & 9713 \\
\hline Barstar 1,2 & 5709.5 & 2162 & 6157 & Staphylococcal nuclease ${ }^{4}$ & 7880 & 5860 & 7620 \\
\hline $\mathrm{BPTI}$ & 2561.5 & 1842 & 2500 & Staphylococcal nuclease ${ }^{1}$ & 8049 & 5173 & 9300 \\
\hline Carbonic anhydrase ${ }^{1,4}$ & 15854.5 & 9900.5 & 15997 & Stefin $A^{1}$ & 5120 & 3635 & 7400 \\
\hline Chymotrypsin $^{3}$ & 12658 & 6838 & 14100 & Stefin $B^{1}$ & 5217 & 3508 & 6700 \\
\hline Chymotrypsin inhibitor $2^{2}$ & 3552 & 1316 & 3014 & Subtilisin BPN ${ }^{1}$ & 15672 & 10308 & 20100 \\
\hline Chymotrypsinogen ${ }^{4}$ & 14550 & 7275 & 15910 & Subtilisin inhibitor ${ }^{1}$ & 4975 & 3568 & 8500 \\
\hline $\mathrm{Cl} 2^{1}$ & 3368 & 2198 & 2500 & T4 Lysozyme ${ }^{1}$ & 9709 & 6709 & 10100 \\
\hline Cyt b5 (tryp fragment) ${ }^{1}$ & 4341 & 3109 & 6000 & T4 Lysozyme ${ }^{2}$ & 10429 & 4411 & 10760 \\
\hline Cytochrome $\mathrm{c}^{3}$ & 4942 & 3358 & 6800 & T4 Lysozyme ${ }^{3}$ & 8643 & 5353 & 11000 \\
\hline Cytochrome c (horse) ${ }^{1}$ & 5716 & 3788 & 5150 & Tendamistat ${ }^{3}$ & 3062 & 2141 & 3600 \\
\hline Cytochrome c (horseheart) ${ }^{2}$ & 6909 & 2761 & 7243 & Tendamistat $^{1}$ & 3338 & 2784 & 2900 \\
\hline Cytochrome c (yeast iso 2$)^{1}$ & 5630 & 4320 & 5200 & Thioredoxin (E. coli) $)^{1,2}$ & 6572.5 & 2879.5 & 7075 \\
\hline Ferricytochrome $^{4}$ & 5540 & 3300 & 7243 & Trypsin inhibitor ${ }^{4}$ & 2640 & 1500 & 3014 \\
\hline G Protein ${ }^{3}$ & 2399 & 1364 & 3600 & Tryptophan synthase, a-subunit ${ }^{2}$ & 17097 & 6050 & 19259 \\
\hline GCN4 1 & 2939 & 2364 & 3000 & Ubiquitin ${ }^{2,3}$ & 4203 & 1724.5 & 5700 \\
\hline HPr (B.s) $)^{1,2}$ & 4883.5 & 2456.5 & 4879 & a-Chymotrypsin 2,4 & 15242 & 6910 & 12644 \\
\hline IgG binding domain of protein $\mathrm{G}^{1,2}$ & 2822.5 & 1556.5 & 2598 & a-Chymotrypsin ${ }^{1}$ & 13808 & 8648 & 12800 \\
\hline IL-1 $\beta^{1}$ & 8817 & 5165 & 8000 & $\alpha$-Chymotrypsinogen ${ }^{1}$ & 14012 & 9127 & 14500 \\
\hline $\mathrm{IL}-1 \beta^{2}$ & 10180 & 3791 & 7913 & $\alpha$-Lactalbumin ${ }^{1}$ & 6773 & 4814 & 7600 \\
\hline Iso-I-cytochrome c (yeast) ${ }^{1,2}$ & 5952 & 3504.5 & 5618 & a-Lactalbumin ${ }^{1}$ & 7027 & 4719 & 7500 \\
\hline Lac repressor headpiece $^{1}$ & 2291 & 1622 & 1300 & & & & \\
\hline Lysozyme (equine) $^{1}$ & 7147 & 5564 & 7500 & Hydrocarbons & & & \\
\hline Lysozyme (hen egg white) $)^{2,4}$ & 7172 & 4146 & 6448 & Benzene $^{5}$ & 217.9 & 0 & 247.3 \\
\hline Lysozyme (hen) ${ }^{1}$ & 7024 & 5315 & 6450 & Butane $^{5}$ & 242.5 & 0 & 365.2 \\
\hline Lysozyme (human) ${ }^{1,2}$ & 7698.5 & 4645 & 6758 & Cyclohexane ${ }^{6}$ & 254.0 & 0 & 360.0 \\
\hline Met-J1,3 & 11344.5 & 7726 & 8950 & Cyclopropane $^{4}$ & 196.0 & 0 & 269.6 \\
\hline Metmyoglobin $^{4}$ & 10218 & 4665 & 11597 & Ethane $^{5}$ & 184.0 & 0 & 274.1 \\
\hline Metmyoglobin (horse) ${ }^{1,2}$ & 9873 & 4698 & 7715 & Ethylbenzene $^{6}$ & 267.8 & 0 & 318.0 \\
\hline Myoglobin ${ }^{1}$ & 8407 & 4793 & 12200 & Hexane $^{6}$ & 296.0 & 0 & 440.0 \\
\hline Myoglobin (whale) ${ }^{3}$ & 9143 & 5679 & 8800 & Isobutane ${ }^{4}$ & 233.0 & 0 & 331.6 \\
\hline OMTKY3 $^{1}$ & 2162 & 1874 & 2650 & I-butene ${ }^{4}$ & 214.0 & 0 & 350.0 \\
\hline Ovomucoid third domain ${ }^{2}$ & 2257 & 1302 & 2470 & Pentane $^{6}$ & 266.0 & 0 & 400.0 \\
\hline Papain 2,4 & 12699 & 7559 & 14113 & Propane $^{5}$ & 212.0 & 0 & 296.7 \\
\hline Papain ${ }^{1}$ & 13071 & 8692 & 13700 & Propylbenzene ${ }^{4}$ & 307.0 & 0 & 391.0 \\
\hline Parvalbumin ${ }^{1}$ & 5750 & 4006 & 5600 & Toluene $^{5}$ & 259.0 & 0 & 311.8 \\
\hline Parvalbumin $\mathrm{b}^{4}$ & 5485 & 3550 & 4605 & & & & \\
\hline Pepsin ${ }^{1}$ & 19584 & 11717 & 18800 & Dipeptides & & & \\
\hline Pepsinogen ${ }^{2,4}$ & 24668.5 & 10520 & 25498 & Cyclic $\mathrm{AA}^{7}$ & 161.4 & 126.2 & 100 \\
\hline Pepsinogen ${ }^{1}$ & 22811 & 14298 & 24100 & Cyclic $\mathrm{AG}^{7}$ & 126.8 & 137.6 & 53 \\
\hline Plasminogen $\mathrm{K} 4$ domain ${ }^{1}$ & 3801 & 3408 & 5200 & Cyclic $\mathrm{GG}^{7}$ & 93.7 & 149.3 & -15 \\
\hline Ribonuclease $\mathrm{A}^{2}$ & 6819 & 3638 & 5150 & Cyclic $\mathrm{LG}^{7}$ & 189.7 & 131.1 & 230 \\
\hline RNase $\mathrm{A}^{3}$ & 5273 & 4141 & 5200 & Cyclic LP ${ }^{7}$ & 268.4 & 98.5 & 316 \\
\hline RNase $A^{1}$ & 5802 & 5468 & 5400 & Cyclic VV ${ }^{7}$ & 266.3 & 100.2 & 320 \\
\hline Ribonuclease $\mathrm{T} 1^{4}$ & 5165 & 3040 & 6908 & & & & \\
\hline
\end{tabular}


Table S2: PDB codes and IDP chain IDs used to determine the ratio between polar and nonpolar surface area burial of IDP interactions. The list contains all 829 PDB codes retrieved from the DIBS ${ }^{8}$ database (version: 28-09-2017, source: dibs.enzim.ttk.mta.hu) and a letter identifying the ID chain. The table shows PDB codes in odd columns and the associated disordered component chain ID in the following column. This list is not filtered based on ID component chain length or the presence of non-standard residues. Filtering is done during processing as described in Script 1. The table is available on GitHub: https://github.com/KULLCentre/papers/tree/master/2021/SR-ID_method-Theisen-et-al

\begin{tabular}{|c|c|c|c|}
\hline $1 \mathrm{AXC}$ & B & 1R8U & A \\
\hline $1 \mathrm{SQQ}$ & I & $3 \mathrm{KQI}$ & B \\
\hline 1CEE & B & $1 Y C Q$ & B \\
\hline 1TBA & A & 2WP2 & $\mathrm{P}$ \\
\hline 1CMK & I & $2 \mathrm{ClA}$ & $\mathrm{L}$ \\
\hline 1TH1 & C & $4 Q Q 4$ & $\mathrm{C}$ \\
\hline 1CQT & I & 3DIW & $\mathrm{C}$ \\
\hline 1WKW & B & $2 \mathrm{P} 2 \mathrm{~T}$ & C \\
\hline 1DEV & B & $3 D \times C$ & B \\
\hline 1VIT & I & $3 \mathrm{~B} 71$ & D \\
\hline 1DPJ & B & 4JOP & C \\
\hline IVIT & 1 & $4 \mathrm{HFZ}$ & B \\
\hline $1 \mathrm{FQJ}$ & C & 3DAC & B \\
\hline 1XTG & B & 3QZS & C \\
\hline $1 \mathrm{FQJ}$ & $\mathrm{C}$ & $3 \mathrm{DAB}$ & B \\
\hline $1 Y C Q$ & B & 3 IKK5 & B \\
\hline 1FQJ & $\mathrm{C}$ & 5FFW & $\mathrm{C}$ \\
\hline 2AUH & B & $3 \mathrm{CYY}$ & C \\
\hline $1 \mathrm{FQJ}$ & C & $4 \cup 68$ & D \\
\hline 2B3G & B & 4A1G & $\mathrm{E}$ \\
\hline 1FV1 & $\mathrm{F}$ & $2 \mathrm{~B} 3 \mathrm{G}$ & B \\
\hline $2 \mathrm{C} 1 \mathrm{~T}$ & D & $1 \times 11$ & $\mathrm{C}$ \\
\hline $1 \mathrm{IBX}$ & B & $31 X S$ & B \\
\hline $1 \mathrm{G} 3 \mathrm{~J}$ & B & $2 \mathrm{KXC}$ & B \\
\hline 1JDH & B & 4BWQ & B \\
\hline $117 \mathrm{X}$ & B & $4 \mathrm{CC} 2$ & B \\
\hline $1 \mathrm{~S} 70$ & B & 4LK9 & B \\
\hline $118 \mathrm{H}$ & A & $3 V 4 Y$ & B \\
\hline $2 \mathrm{KWF}$ & B & $1 \mathrm{~T} 08$ & C \\
\hline $1 \mathrm{~J} 2 \mathrm{~J}$ & B & $2 \mathrm{MSR}$ & A \\
\hline $2 \mathrm{C} 52$ & A & $4 \mathrm{OZ1}$ & C \\
\hline 1JSU & C & 3DOW & B \\
\hline 3TU5 & B & $3 \mathrm{GV} 6$ & B \\
\hline 1JSU & C & 2L1B & B \\
\hline 3T5G & A & 3JTI & B \\
\hline $1 \mathrm{KDX}$ & B & $3 \mathrm{GCl}$ & $\mathrm{P}$ \\
\hline $1 \mathrm{~L} 8 \mathrm{C}$ & B & 1QNZ & $\mathrm{P}$ \\
\hline 1PQ1 & A & $30 B U$ & B \\
\hline $1 \mathrm{MVO}$ & A & $1 \mathrm{NPQ}$ & B \\
\hline $2 \mathrm{KGI}$ & $\mathrm{B}$ & $2 R Q G$ & A \\
\hline $109 \mathrm{~A}$ & B & 1EMU & B \\
\hline $310 Z$ & B & $1 \mathrm{P} 4 \mathrm{Q}$ & A \\
\hline 1ONV & B & 1OQN & $\mathrm{C}$ \\
\hline 1PJN & A & $2 \mathrm{ROZ}$ & A \\
\hline 1P16 & D & $1 \mathrm{KNE}$ & $\mathrm{P}$ \\
\hline $1 \mathrm{KY} 6$ & $\mathrm{P}$ & $2 \mathrm{LOX}$ & B \\
\hline $1 \mathrm{P} 4 \mathrm{Q}$ & A & 1QOW & A \\
\hline $1 \mathrm{SCJ}$ & B & 2MKR & B \\
\hline $1 \mathrm{Q} 68$ & A & $2 \mathrm{M} 14$ & B \\
\hline $2 \mathrm{ROL}$ & B & $3 \mathrm{HPW}$ & C \\
\hline 1RF8 & B & $1 \mathrm{PDQ}$ & B \\
\hline $1 \mathrm{MIU}$ & B & 5URN & B \\
\hline 1SBO & B & 2RVB & A \\
\hline $2 \times 72$ & B & 5UCL & B \\
\hline $1 \mathrm{SC} 5$ & B & $2 \mathrm{MKP}$ & I \\
\hline 3N2D & $\mathrm{B}$ & 2RS9 & A \\
\hline 1SQK & B & 4QYD & B \\
\hline $\begin{array}{l}\text { 1MVO } \\
\text { a }\end{array}$ & A & 1TH1 & $\mathrm{C}$ \\
\hline 1JSP & A & $1 \mathrm{QZ7}$ & B \\
\hline 2RUK & A & $109 \mathrm{U}$ & B \\
\hline $2 \mathrm{KPL}$ & B & $2 \mathrm{~L} 12$ & $\mathrm{~B}$ \\
\hline 2KJE & B & 2L11 & B \\
\hline $2 \mathrm{MZD}$ & B & 4062 & D \\
\hline 2LSP & A & 3FDT & $\mathrm{T}$ \\
\hline 2KFT & B & $2 \mathrm{YBF}$ & B \\
\hline 2LPO & B & $5 \mathrm{HJC}$ & B \\
\hline 2ASQ & B & 3ASL & B \\
\hline $1 \mathrm{H} 3 \mathrm{H}$ & B & 2JMJ & $\mathrm{P}$ \\
\hline 2GSO & B & $3 \mathrm{G} 7 \mathrm{~L}$ & $\mathrm{P}$ \\
\hline $2 \mathrm{~K} 8 \mathrm{~F}$ & B & $307 \mathrm{~A}$ & B \\
\hline 2LY4 & $B$ & 2RR4 & B \\
\hline 3SV1 & $\mathrm{D}$ & 3TZ1 & B \\
\hline $2 \mathrm{~K} 2 \mathrm{U}$ & B & $2 M 8 S$ & B \\
\hline $2 \mathrm{ROL}$ & B & 2KTB & A \\
\hline 2JNW & B & 2RNX & B \\
\hline 1AOU & $\mathrm{P}$ & 5FFV & $\mathrm{C}$ \\
\hline 1TCE & B & $4 \mathrm{HCZ}$ & C \\
\hline 2LTO & B & $5 \mathrm{LXH}$ & $\mathrm{E}$ \\
\hline $2 R Q U$ & $\mathrm{~B}$ & 1PFB & $\mathrm{B}$ \\
\hline $1 \mathrm{OPI}$ & B & 3TCJ & $\mathrm{T}$ \\
\hline 1ONV & B & $2 \mathrm{VNF}$ & B \\
\hline $1 \mathrm{~T} 6 \mathrm{O}$ & B & 2WP1 & $\mathrm{P}$ \\
\hline $2 \mathrm{~A} 4 \mathrm{~J}$ & B & $1 \mathrm{JGN}$ & B \\
\hline 2KA6 & B & $5 \mathrm{~B} 77$ & B \\
\hline 1JU5 & B & 3NFK & $\mathrm{C}$ \\
\hline 2KA4 & B & $4 Q Y L$ & $\mathrm{E}$ \\
\hline $2 \times 4 \mathrm{~W}$ & B & $2 \times 04$ & $\mathrm{C}$ \\
\hline $2 \mathrm{RPQ}$ & B & 2JKR & $\mathrm{P}$ \\
\hline 2RNY & B & $2 K G B$ & I \\
\hline 2KQS & B & 2VOG & B \\
\hline 2L75 & B & $3 U V Y$ & B \\
\hline 2LWW & B & 3UVX & B \\
\hline $1 \mathrm{E} 91$ & B & 3UW9 & $\mathrm{E}$ \\
\hline $2 \mathrm{BZW}$ & B & 3UVW & $B$ \\
\hline $1 \mathrm{~L} 3 \mathrm{E}$ & A & $4 \mathrm{KV} 1$ & $\mathrm{C}$ \\
\hline
\end{tabular}

5UWP D SUWQ D

2JD5

$112 \mathrm{~W}$

1JYO E

$306 \mathrm{Q}$

उKXY T

4JMF A

$4 \mathrm{G} 6 \mathrm{~T} \quad \mathrm{~B}$

1TTW B

$\begin{array}{cc}2 \mathrm{MY} 3 & \mathrm{~B} \\ 4 \mathrm{BJT} & \mathrm{D}\end{array}$

$5 A 2 P$

2VCP D

3C6W B

2FSA P

2DVQ P

$\begin{array}{ll}3 \mathrm{LQ} & \mathrm{R} \\ \text { 3LQJ } & \mathrm{Q}\end{array}$

1JM4

3034

3036 E

5CW7 A

$\begin{array}{rl}1 \mathrm{JLU} & \mathrm{S} \\ 2 \mathrm{FUU} & \mathrm{B}\end{array}$

1L8C B

$\begin{array}{rr}\text { 3T6R } & \text { D } \\ \text { 2RNW } & \text { B }\end{array}$

2PUY E

2L1L A

2W84 $\mathrm{B}$

2JQ9 B

3VXW

3BL2 C

$\begin{array}{rr}\text { 1EE5 } & B \\ \text { 4UQT } & B\end{array}$

1P9D S

2LE8 B

2N1G B

2ND1 B

2ND0

2NCZ B

2NN5 B

2V52

3MN5 S

$\begin{array}{ll}3 \text { 3MN5 } & \mathrm{S} \\ \text { 3MN7 } & \mathrm{S}\end{array}$

2EUU $\mathrm{P}$

$4 \mathrm{~N} 4 \mathrm{~F} \quad \mathrm{C}$

SSOW

4LKA $\mathrm{B}$

4LLB C

4UE8 B

5UWH

5UWI D 
Table S3: Spolar-Record analysis of previously analyzed interactions. Reanalysis of data from Table 4 of the SR method paper

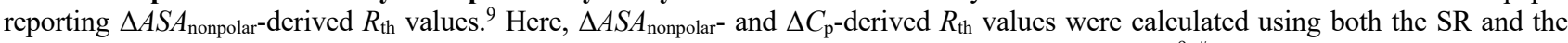
$\mathrm{SR}_{\mathrm{ID}}$ analysis. $R_{\text {str }}$ is the structure-based estimate of the number of residues folding upon binding. ${ }^{9}$ "For interactions which are not prototypical ID-based protein-protein interactions, the $\triangle A S A_{\text {nonpolar }}$ derived results may be more appropriate than the $\Delta C_{\mathrm{p}}$ derived results. ${ }^{\dagger}$ Multimeric assemblies have larger rototranslational entropy contributions.

\begin{tabular}{|c|c|c|c|c|c|c|}
\hline Interaction & $T_{\mathrm{S}}(\mathrm{K})$ & $\Delta C_{\mathrm{p}}\left(\mathrm{J} \mathrm{mol}^{-1} \mathrm{~K}^{-1}\right)$ & $\triangle A S A_{\text {nonpolar }}\left(\AA^{2}\right)$ & $R_{\text {th }}$ & $R_{\mathrm{th}, \mathrm{ID}}$ & $R_{\text {str }}$ \\
\hline \multirow[t]{2}{*}{ Angiotensin II + antibody Fab 131} & 312 & -1000 & & 3 & 10 & \\
\hline & 312 & & -990 & 3 & 8 & 8 \\
\hline \multirow[t]{2}{*}{ Avidin + biotin $^{\#}$} & 291 & -990 & & 7 & 15 & \\
\hline & 291 & & -940 & 6 & 11 & 9 \\
\hline \multirow[t]{2}{*}{ S-peptide + S-protein } & 253 & -1780 & & 34 & 47 & \\
\hline & 253 & & -1080 & 17 & 22 & 15 \\
\hline \multirow[t]{2}{*}{ L-tryptophan + apo Trp R monomer ${ }^{\#}$} & 263 & -960 & & 12 & 21 & \\
\hline & 263 & & -1030 & 14 & 18 & 17 \\
\hline \multirow[t]{2}{*}{ Holo Trp R dimer + trp operator $\mathrm{DNA}^{\#}$} & 319 & -2260 & & 16 & 25 & \\
\hline & 319 & & -2420 & 17 & 22 & 16 \\
\hline \multirow[t]{2}{*}{2 GR DBD + DNA $^{\# \dagger}$} & 308 & -4180 & & 37 & 57 & \\
\hline & 308 & & -3950 & 33 & 42 & 40 \\
\hline \multirow[t]{2}{*}{3 glucagon trimerization ${ }^{\# \dagger}$} & 271 & -2640 & & 36 & 55 & \\
\hline & 271 & & -3210 & 47 & 56 & $48-72$ \\
\hline \multirow[t]{2}{*}{4 melittin tetramerization ${ }^{\dagger}$} & 313 & -4600 & & 29 & 53 & \\
\hline & 313 & & -7110 & 58 & 72 & 104 \\
\hline \multirow[t]{2}{*}{2 arc repressor dimerization ${ }^{\#}$} & 289 & -5860 & & 89 & 113 & \\
\hline & 289 & & -5670 & 85 & 89 & $80-92$ \\
\hline \multirow[t]{2}{*}{$2 \lambda$ cro repressor dimerization ${ }^{\#}$} & 287 & -6400 & & 101 & 127 & \\
\hline & 287 & & -6540 & 102 & 106 & 120 \\
\hline
\end{tabular}


Table S4: Spolar-Record analysis of ID-based protein-protein interactions with available thermodynamic data. Application of the $\mathrm{SR}$ and $\mathrm{SR}_{\mathrm{ID}}$ methods to a selection of ID-based protein-protein interaction systems with various degrees of coupled folding and binding.

\begin{tabular}{|c|c|c|c|c|}
\hline Interaction & $T_{\mathrm{S}}(\mathrm{K})$ & $\Delta C_{\mathrm{p}}\left(\mathrm{J} \mathrm{mol}^{-1} \mathrm{~K}^{-1}\right)$ & $R_{\mathrm{th}}$ & $R_{\mathrm{th}, \mathrm{ID}}$ \\
\hline \multicolumn{5}{|c|}{ Interactions previously analyzed using the SR method } \\
\hline $\mathrm{p} 27-\mathrm{KID}+\mathrm{Cdk} 2^{10}$ & 261 & -3110 & 61 & 79 \\
\hline p27-KID + Cyclin $\mathrm{A}^{10}$ & 287 & -2520 & 34 & 47 \\
\hline p27-KID + Cdk2-Cyclin A ${ }^{10}$ & 265 & -3650 & 70 & 90 \\
\hline \multicolumn{5}{|c|}{ Interactions not previously analyzed using the SR method } \\
\hline $\mathrm{I} \kappa \mathrm{B} \alpha+\mathrm{RelA}^{-N L S}{ }^{11}$ & 304 & -1670 & 14 & 23 \\
\hline $\mathrm{FCP} 1+\operatorname{Rap} 74^{12}$ & 327 & -1000 & 1 & 7 \\
\hline Cambrian NCBD $+\mathrm{CID}^{13}$ & 292 & -3100 & 41 & 55 \\
\hline Ordovician-Silurian NCBD + CID $^{13}$ & 297 & -3260 & 40 & 55 \\
\hline Extant human NCBD $+\mathrm{CID}^{13}$ & 295 & -4020 & 54 & 70 \\
\hline MAGI1-PDZ1 + HPV16E6 L0|V'14 & 310 & -1970 & 16 & 25 \\
\hline MAGI1-PDZ1 SLV|GGG + HPV16E16 L0|V'14 & 337 & -630 & -4 & 1 \\
\hline
\end{tabular}



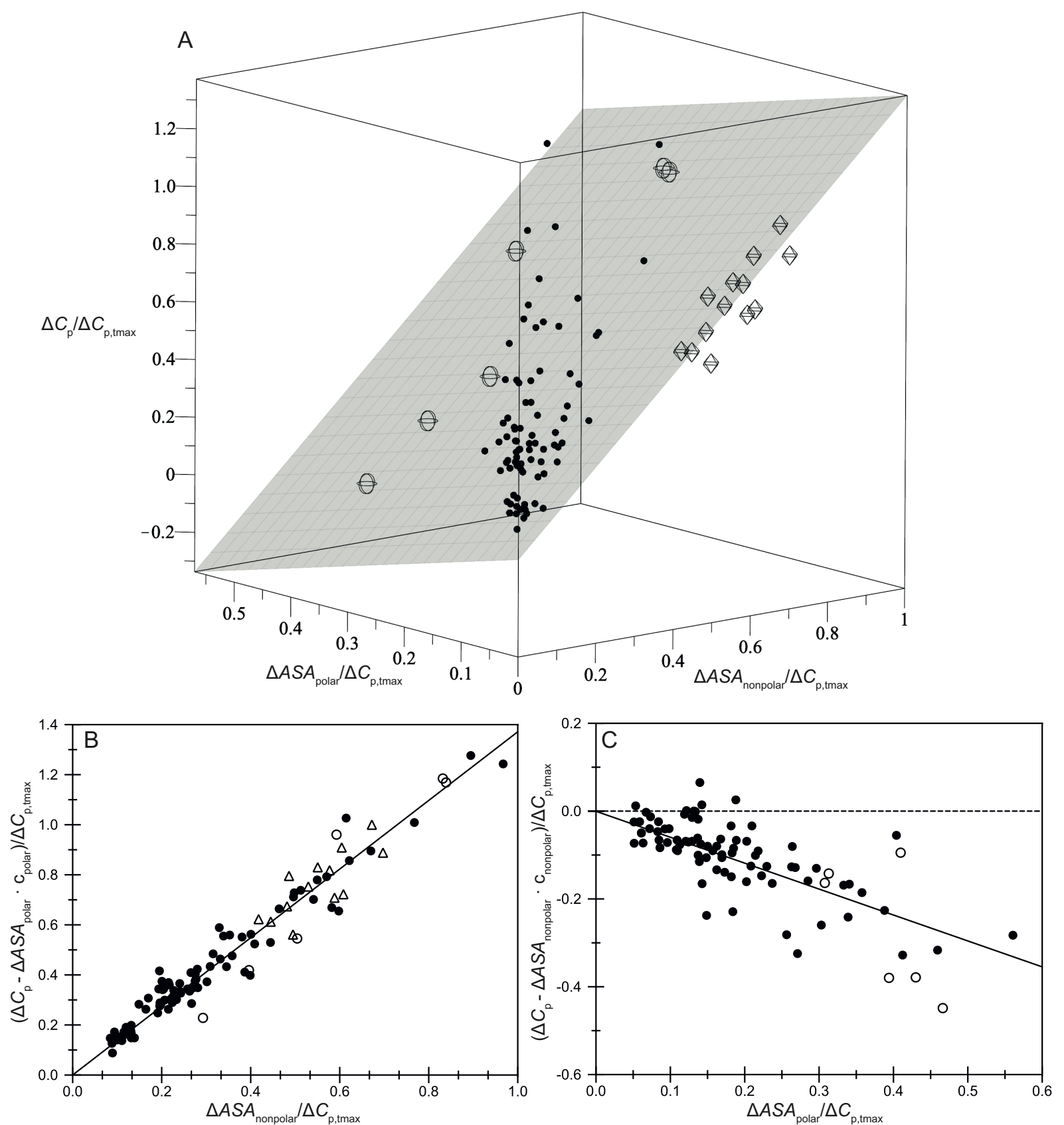

Figure S1. Fitting of heat capacity changes for solvation of polar and nonpolar surface. (A) Three-dimensional plot of the normalized data. The plane represents the best fit: $\Delta C_{\mathrm{p}}=1.37 \pm 0.06 \cdot \Delta A S A_{\text {nonpolar }}-0.59 \pm 0.12 \cdot \Delta A S A_{\text {polar }}$. Non-normalized data are shown in Table S1. Solid circles show protein data, 'spheres' show dipeptide data and diamonds show hydrocarbon data. (B and C) show the nonpolar and polar correlations, respectively. Solid circles $(\bullet)$ represent protein data, open circles $(\circ)$ dipeptide data and triangles $(\Delta)$ hydrocarbon data. For (B), each data point represents the total, normalized, $\Delta C_{\mathrm{p}}$ minus the polar contribution, estimated from the provided polar surface area change and the fitted coefficient, plotted against the normalized change in nonpolar surface area, scaled by the maximum $\Delta C_{\mathrm{p}}$ of the data type. (C) is the same as (B) but looking at the polar correlation. The 'tmax' subscript indicates that the value refers to the maximum within the data type. The solid lines indicate the nonpolar and polar components of the two-variable linear fit. $\mathrm{R}^{2}$ value of the fit is 0.97 . Surface area coefficients: $c_{\text {nonpolar }}=1.37 \mathrm{~J} \mathrm{~mol}^{-1} \mathrm{~K}^{-1} \AA^{-2}$ and $\mathrm{c}_{\text {polar }}=-0.59 \mathrm{~J} \mathrm{~mol}^{-1} \mathrm{~K}^{-1} \AA^{-2}$. 

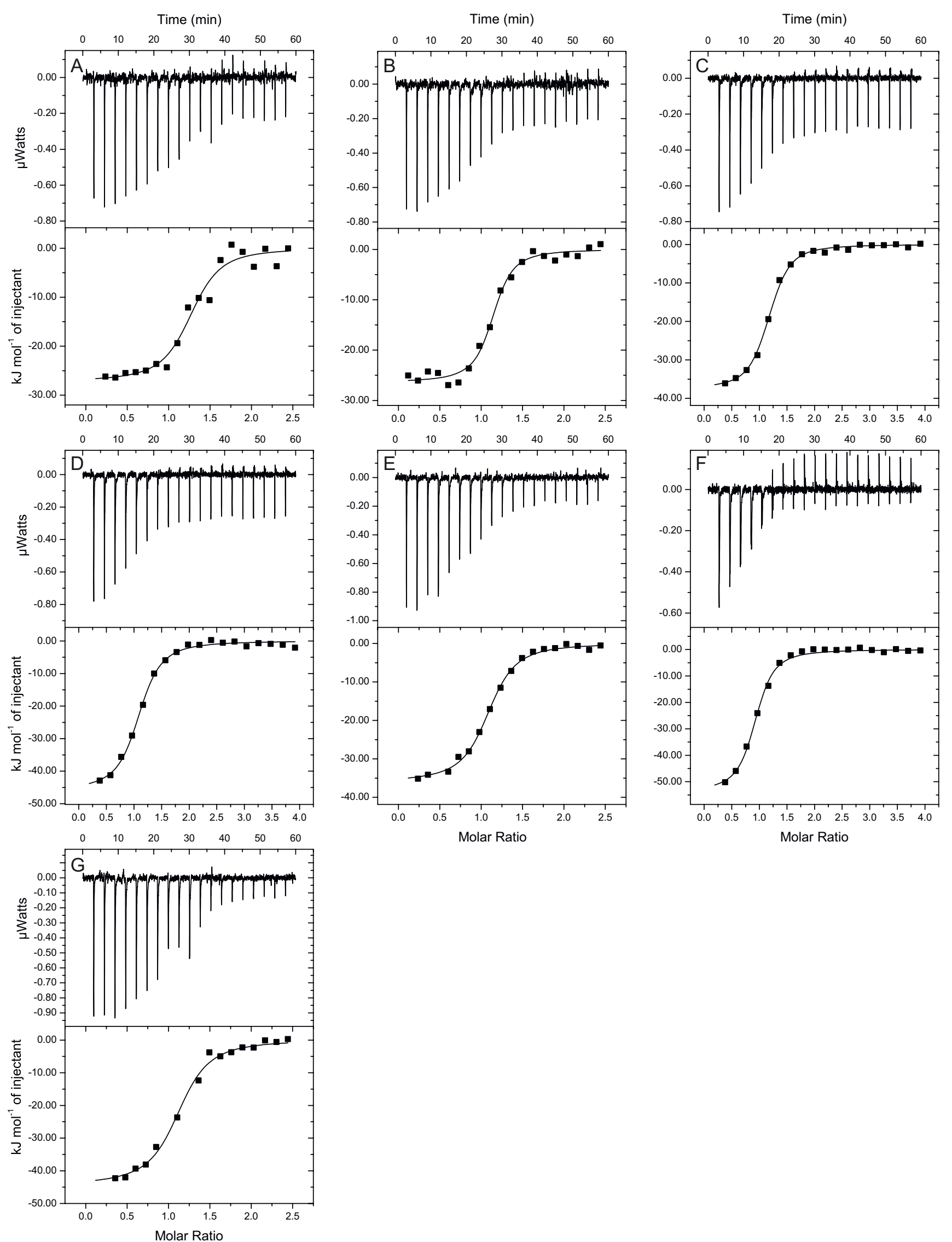

Figure S2. Representative isotherms from ITC experiments conducted with DREB2A $255-272$ over a range of temperatures. The experiments were conducted with DREB2 $\mathrm{A}_{255-272}$ in the cell and RCD1-RST ${ }_{499-572}$ in the syringe. Experimental concentrations vary between experiments (see METHODS). (A): $12.7^{\circ} \mathrm{C},(\mathrm{B}): 15.0^{\circ} \mathrm{C},(\mathrm{C}): 17.5^{\circ} \mathrm{C},(\mathrm{D}): 20.0^{\circ} \mathrm{C},(\mathrm{E}): 22.5^{\circ} \mathrm{C},(\mathrm{F}): 25.0^{\circ} \mathrm{C},(\mathrm{G}): 27.5^{\circ} \mathrm{C}$. 

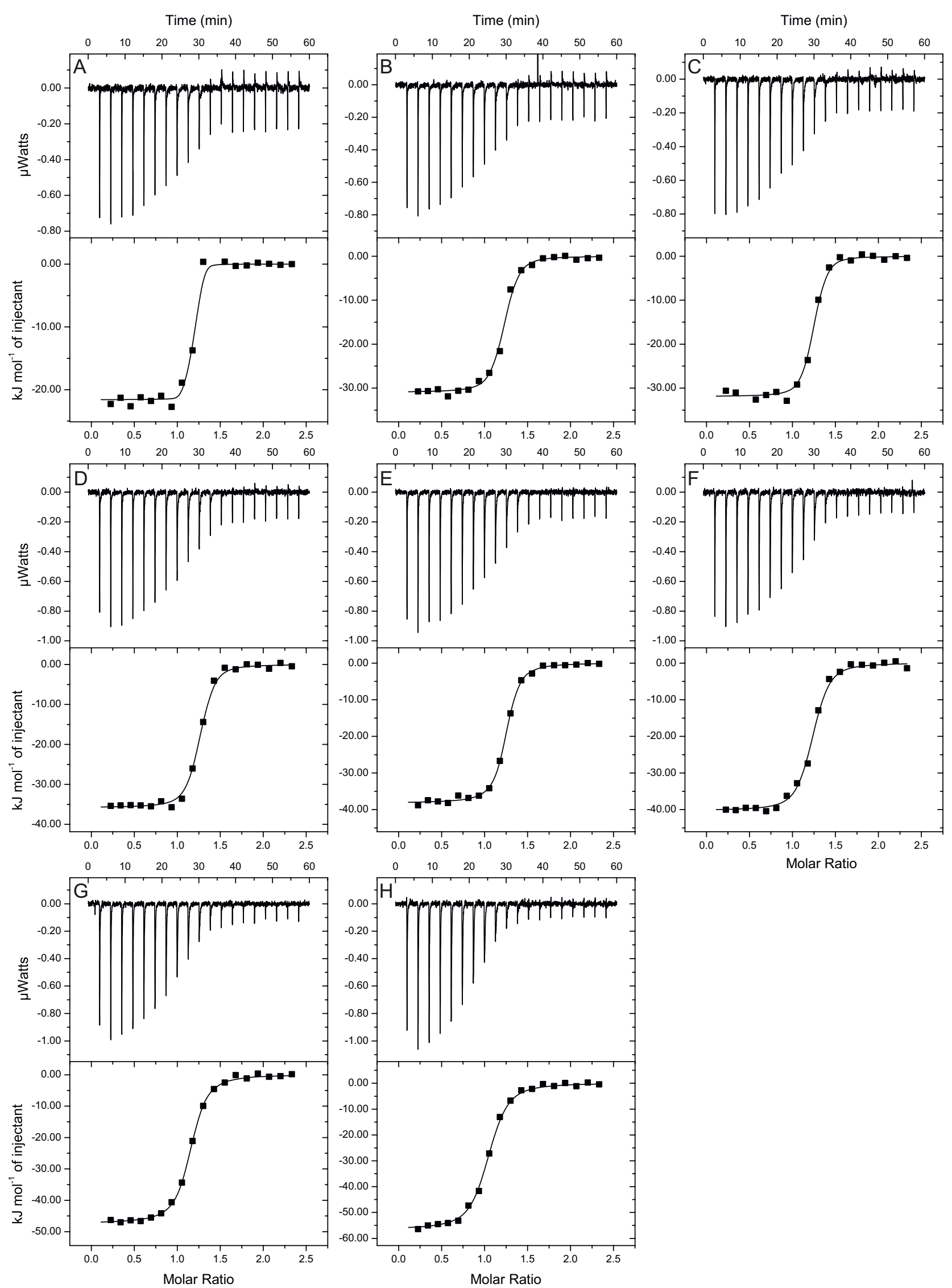

Figure S3. Representative isotherms from ITC experiments conducted with DREB2 $\mathrm{A}_{250-287}$ over a range of temperatures. The experiments were conducted with DREB2 $\mathrm{A}_{250-287}$ in the cell and RCD1-RST $499-572$ in the syringe. Experimental concentrations vary between experiments (see METHODS). (A): $12.5^{\circ} \mathrm{C},(\mathrm{B}): 15.0^{\circ} \mathrm{C},(\mathrm{C}): 17.5^{\circ} \mathrm{C},(\mathrm{D}): 20.0^{\circ} \mathrm{C},(\mathrm{E}): 22.5^{\circ} \mathrm{C},(\mathrm{F}): 25.0^{\circ} \mathrm{C},(\mathrm{G}): 27.5^{\circ} \mathrm{C}$, (H): $30.0{ }^{\circ} \mathrm{C}$. 
Time $(\min )$
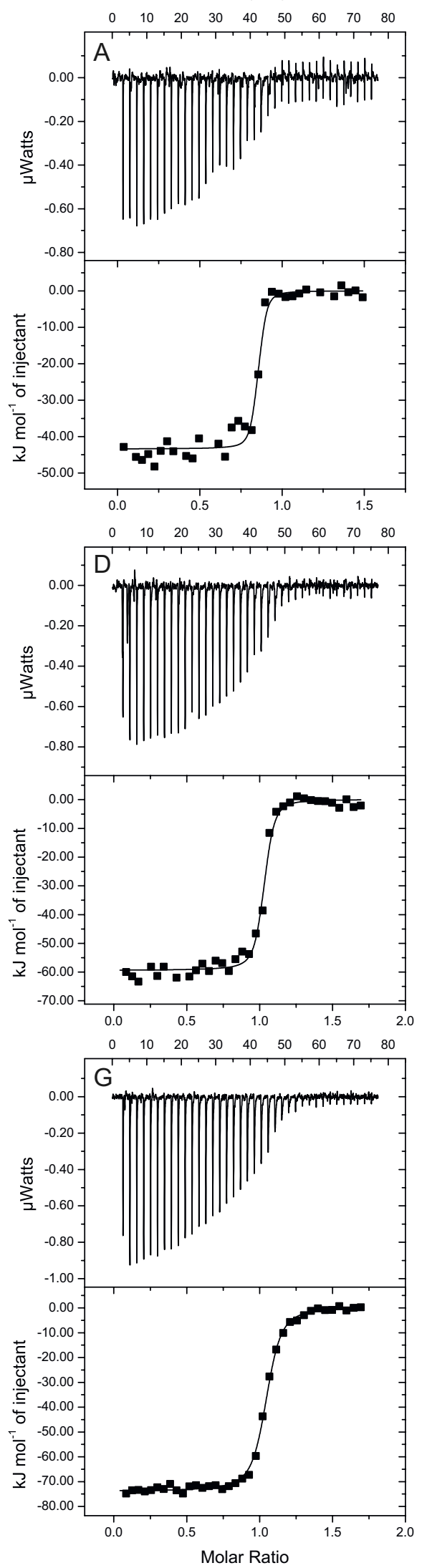

Time $(\min )$
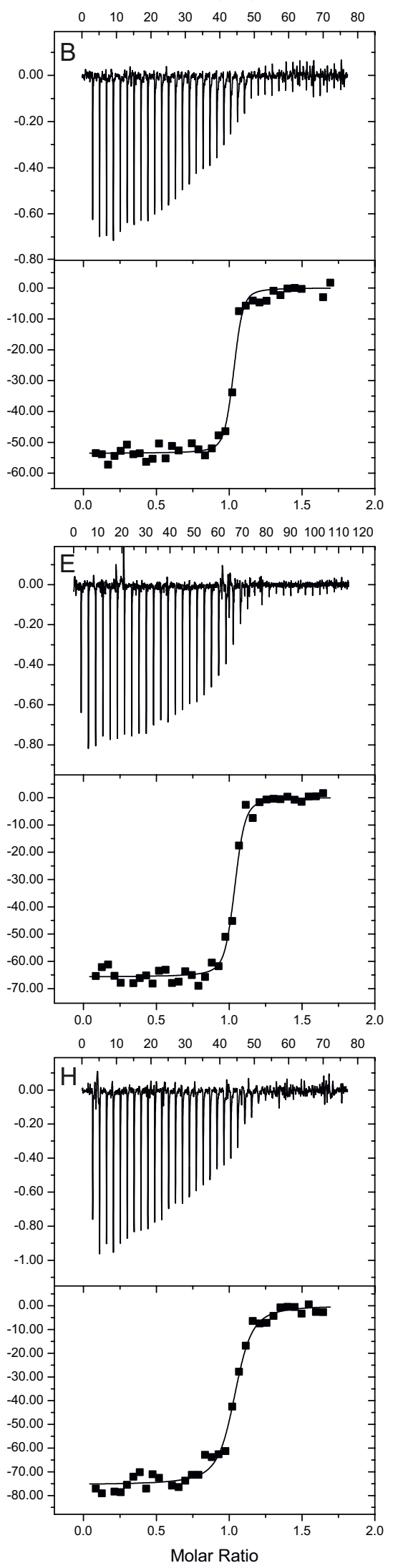

Time (min)
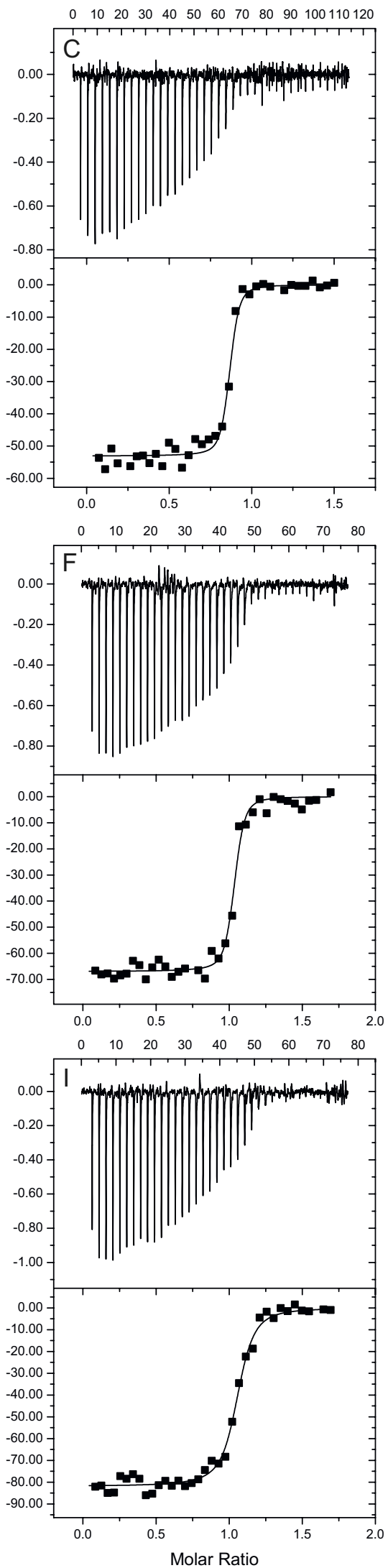

Figure S4. Representative isotherms from ITC experiments conducted with DREB2A $\mathrm{A}_{243-272}$ over a range of temperatures. The experiments were conducted with DREB2 $\mathrm{A}_{243-272}$ in the cell and RCD1-RST ${ }_{499-572}$ in the syringe. Experimental concentrations vary between experiments (see METHODS). (A): $12.5^{\circ} \mathrm{C},(\mathrm{B}): 15.0^{\circ} \mathrm{C},(\mathrm{C}): 17.5^{\circ} \mathrm{C},(\mathrm{D}): 20.0^{\circ} \mathrm{C},(\mathrm{E}): 22.5^{\circ} \mathrm{C},(\mathrm{F}): 25.0^{\circ} \mathrm{C},(\mathrm{G}): 27.5^{\circ} \mathrm{C}$, (H): $30.0^{\circ} \mathrm{C}$, (I): $32.5^{\circ} \mathrm{C}$. 

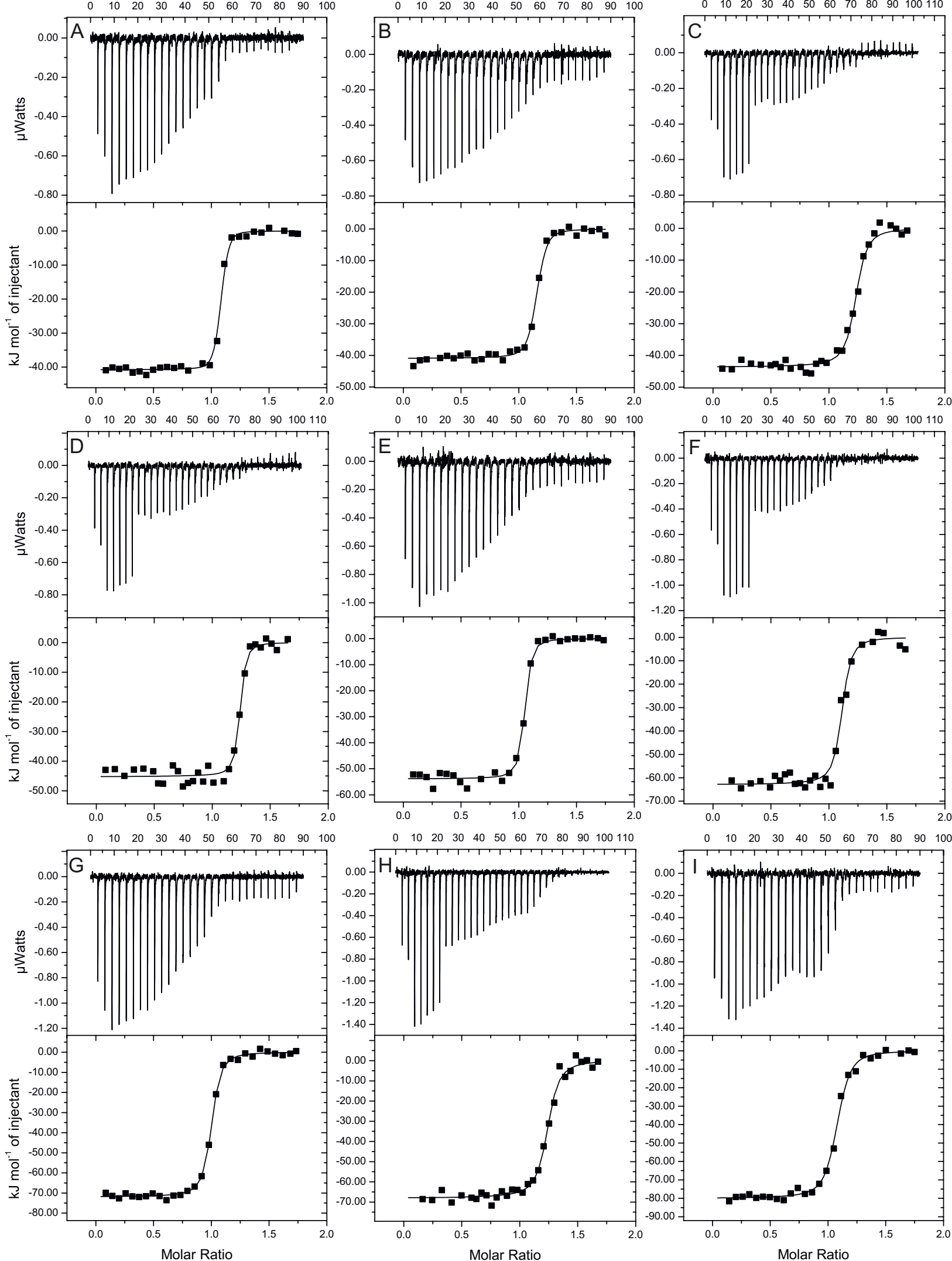

Figure S5. Representative isotherms from ITC experiments conducted with DREB2 $A_{234-287}$ over a range of temperatures. The experiments were conducted with DREB2 $\mathrm{A}_{234-287}$ in the cell and RCD1-RST $499-572$ in the syringe. Experimental concentrations vary between experiments (see METHODS). Some experiments used a few larger injections during the initial half of the titration. (A): 10.0 ${ }^{\circ} \mathrm{C},(\mathrm{B}): 12.5^{\circ} \mathrm{C},(\mathrm{C}): 15.0^{\circ} \mathrm{C},(\mathrm{D}): 17.5^{\circ} \mathrm{C},(\mathrm{E}): 20.0^{\circ} \mathrm{C},(\mathrm{F}): 22.5^{\circ} \mathrm{C},(\mathrm{G}): 27.5^{\circ} \mathrm{C},(\mathrm{H}): 30.0^{\circ} \mathrm{C},(\mathrm{I}): 32.5^{\circ} \mathrm{C}$. 

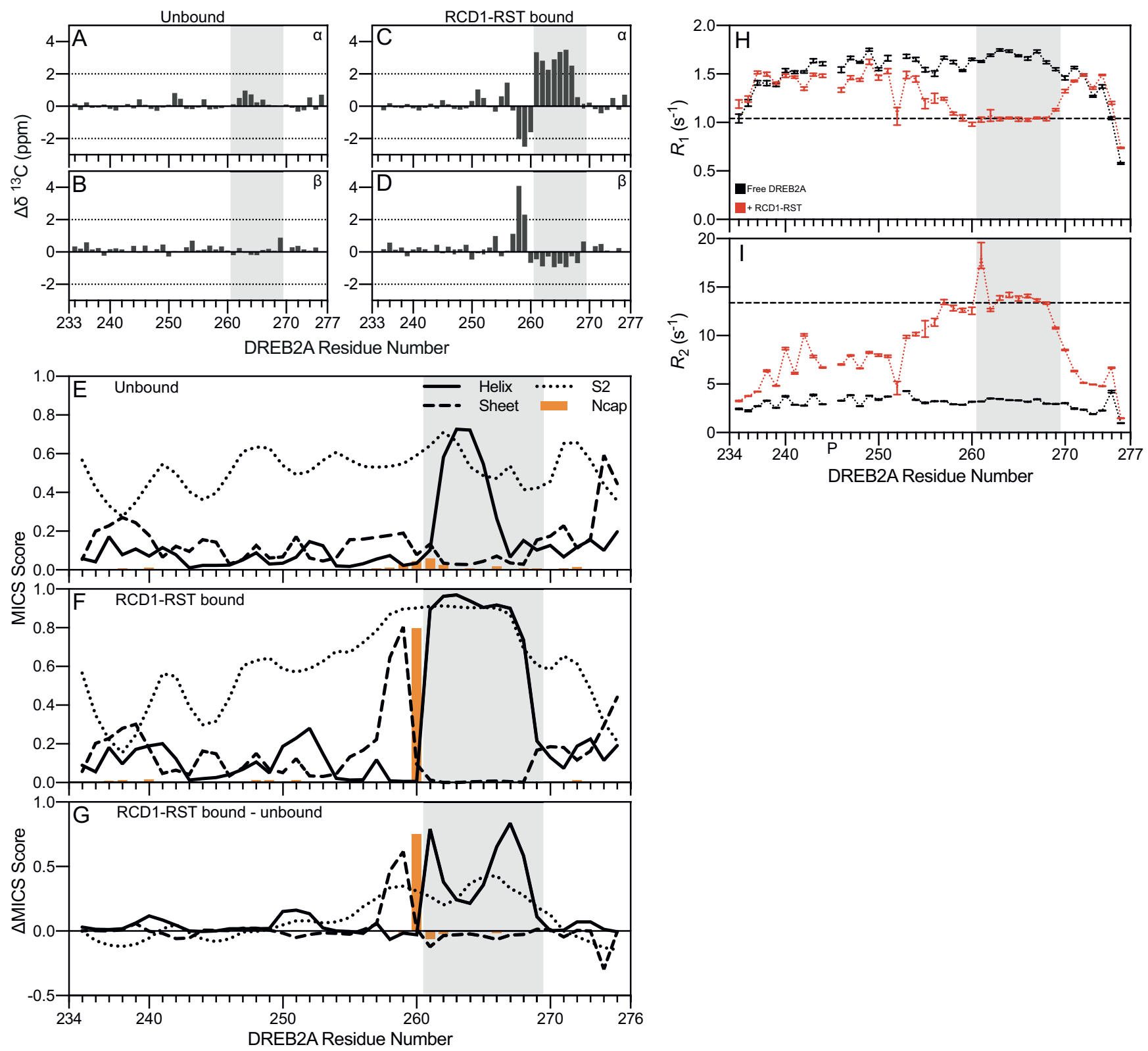

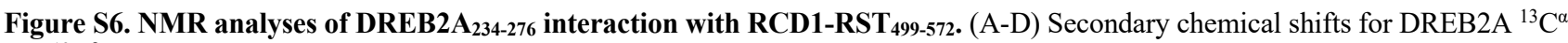
and ${ }^{13} \mathrm{C}^{\beta}$ in the free state (A and B) and in the RCD1-RST bound state (C and D). Secondary chemical shifts were calculated as described in METHODS. (E-G) Analysis of the NMR chemical shift data using the MICS tool. (E and F) MICS predictions of the free and RCD1RST bound state of DREB2A. (G) Difference between free and bound DREB2A. S2 is the Wishart RCI chemical shift order parameter. ${ }^{15}$ The order parameter indicates limited chemical shift evidence of structuring of the DREB2A N-terminal flanking region upon binding to RST. (H and I) NMR longitudinal and transverse ${ }^{15} \mathrm{~N}$ relaxation rates of ${ }^{13} \mathrm{C}-,{ }^{15} \mathrm{~N}$-labeled DREB2 $\mathrm{A}_{234-276}$ in free and RCD1-RST bound states. The data was recorded at $25^{\circ} \mathrm{C}$ on an $800 \mathrm{MHz}\left({ }^{1} \mathrm{H}\right)$ instrument. Error bars represent fit parameter errors. The dashed lines show the mean ${ }^{15} \mathrm{~N}$ relaxation rates obtained for the folded regions of ${ }^{13} \mathrm{C}-$, ${ }^{15} \mathrm{~N}$-labeled RCD1-RST in complex with unlabeled DREB2A $\mathrm{A}_{234-276}$ recorded at $25{ }^{\circ} \mathrm{C}$ on the same $800 \mathrm{MHz}$ instrument. Grey background shows residues which are helical in complex. ${ }^{16}$ 

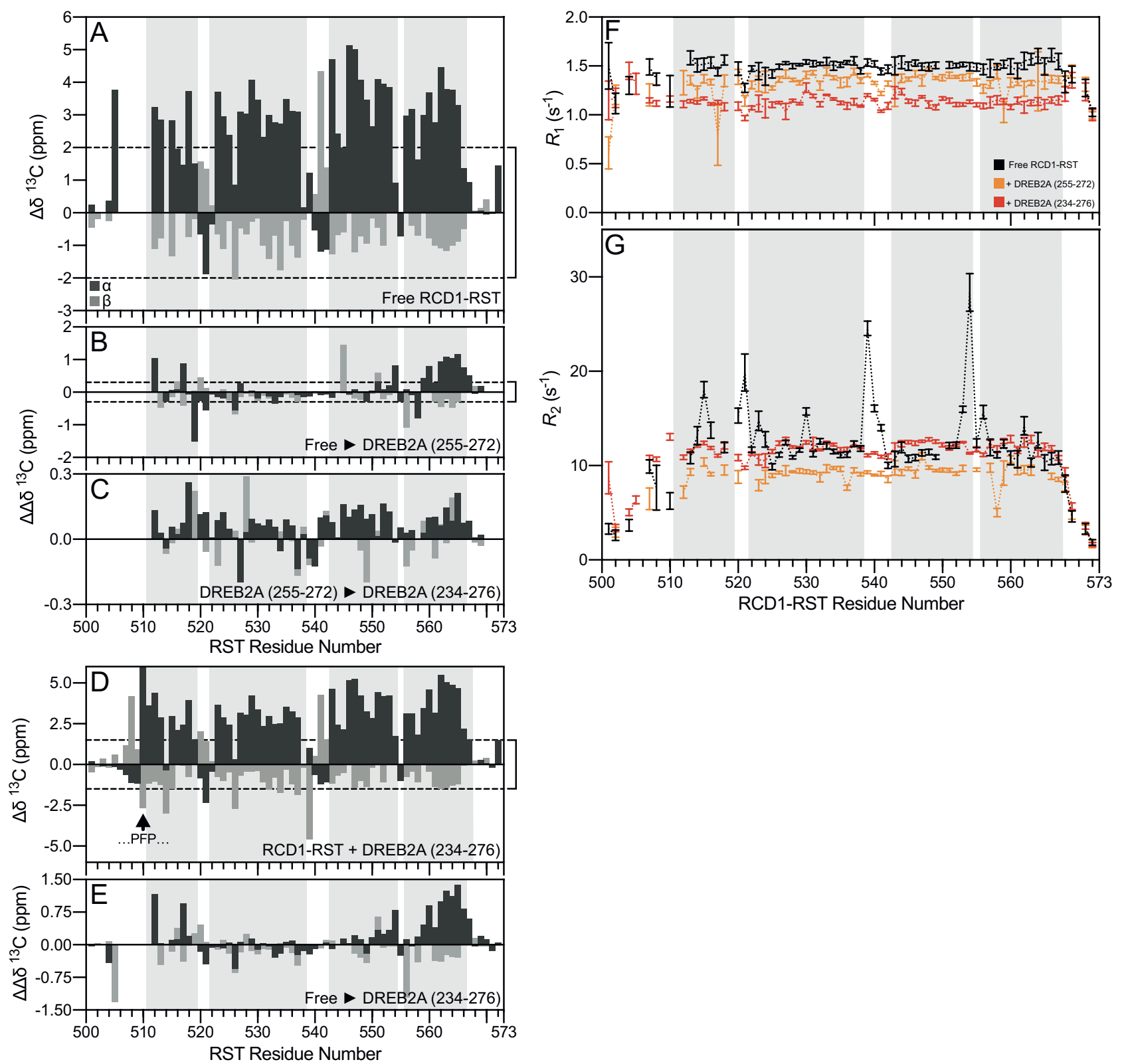

Figure S7. NMR analyses of the RCD1-RST ${ }_{499-572}$ interaction with DREB2A. (A-E) ${ }^{13} \mathrm{C}$ secondary chemical shift values where dark grey represents $C^{\alpha}$ and light represents $C^{\beta}$. For $(A, B$ and $D)$, the bracket on the right side indicates the y-axis range of the following plot. (A) Values for unbound RST. (B) Differences between unbound RST and RST in complex with the short DREB2 $\mathrm{A}_{255-272}$ fragment. (C) Difference in secondary chemical shifts between RCD1-RST bound to DREB2A $255-272$ and RCD1-RST bound to the longer DREB2A $_{234-276}$ fragment. (D) Secondary chemical shifts values for RST in complex with DREB2A $234-276$. (E) Difference between free RCD1-RST and RCD1-RST bound to DREB2A $\mathrm{A}_{234-276 .}$. The $\Delta \delta{ }^{13} \mathrm{C}^{\alpha}$ value of F510 in (D) is $\sim 9 \mathrm{ppm}$. Secondary chemical shifts were calculated as described in METHODS. ( $F$ and G) Longitudinal and transverse ${ }^{15} \mathrm{~N}$ relaxation rates of ${ }^{15} \mathrm{~N}$-labeled RCD1-RST $499-572$ in free and different DREB2A bound states. The data was recorded at $25{ }^{\circ} \mathrm{C}$ on the $750 \mathrm{MHz}\left({ }^{1} \mathrm{H}\right)$ instrument. Grey background shows residues which are helical in complex. ${ }^{16}$ 


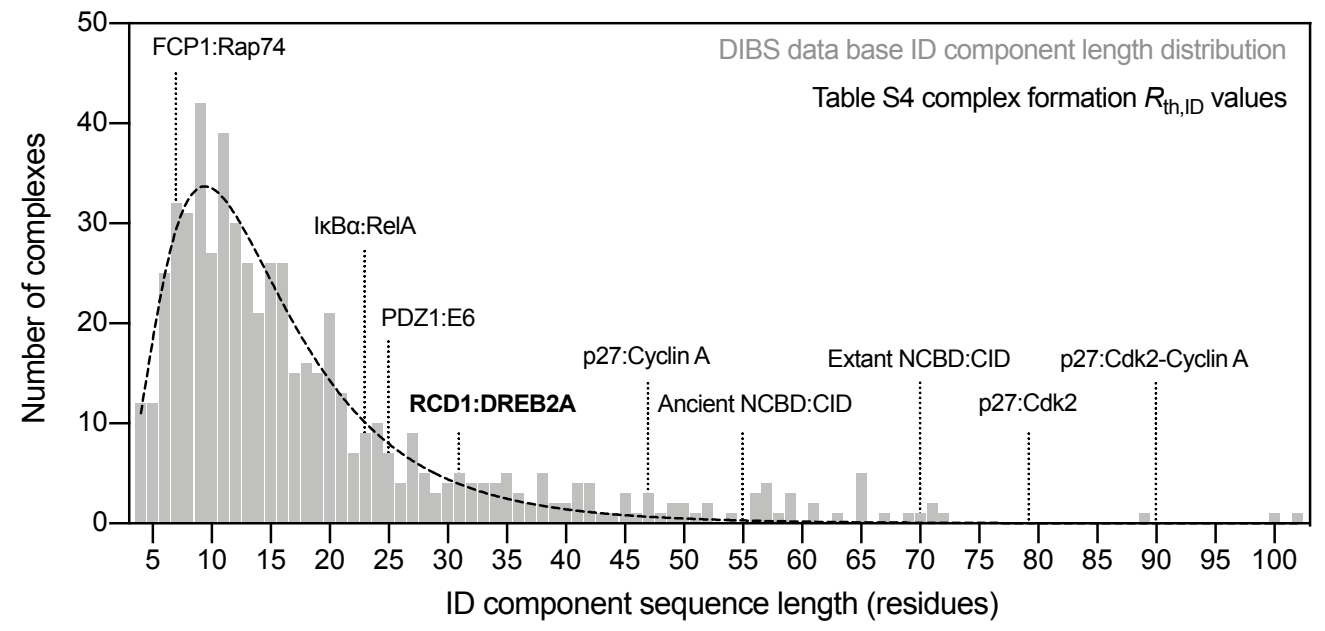

Figure S8: Distribution of ID component chain lengths used for determining ratio of polar to nonpolar surface burial. Length distribution of the ID components of each of the 577 protein complexes from the DIBS ${ }^{8}$ data set used to determine the ratio of polar to nonpolar surface burial for ID interactions. The grey bars indicate the number of complexes with ID components of a given length. Only three complexes have ID components longer than 72 residues. The dashed line shows a log-normal fit of the distribution. The RCD1RST:DREB2A $243-272$ interaction (bold) and the interactions shown in Table S4 are annotated by their $R_{\mathrm{th}, I D}$ values. 
Script 1. PyMOL script for calculating exposed surface of protein structures. The script reads a line separated list of PDB codes including the ID chain identifier and returns surface areas for the complex and for the folded protein without the ID chain. In addition, the ID sequence is returned for processing of the unbound ID cosmponent. Input data is shown in Table S2. Both total, polar and nonpolar surface area are calculated. PyMOL employs a Shrake-Rupley-like approximation of the rolling probe method by extending the van der Waals' radius of each atom by the radius of a water molecule. The algorithm draws a grid of points on the extended van der Waals' surface and calculates the number of these points not hidden by other extended van der Waals' spheres. ${ }^{17}$ Polar surface area is defined as exposed 'dots' originating from oxygen and nitrogen atoms, while non-polar surface area originates from carbon and sulfur atoms. Hydrogen atoms are not considered explicitly. The script is developed for PyMOL v2.2.0. The script is available on GitHub: https://github.com/KULL-Centre/papers/tree/master/2021/SR-ID_method-Theisen-et-al

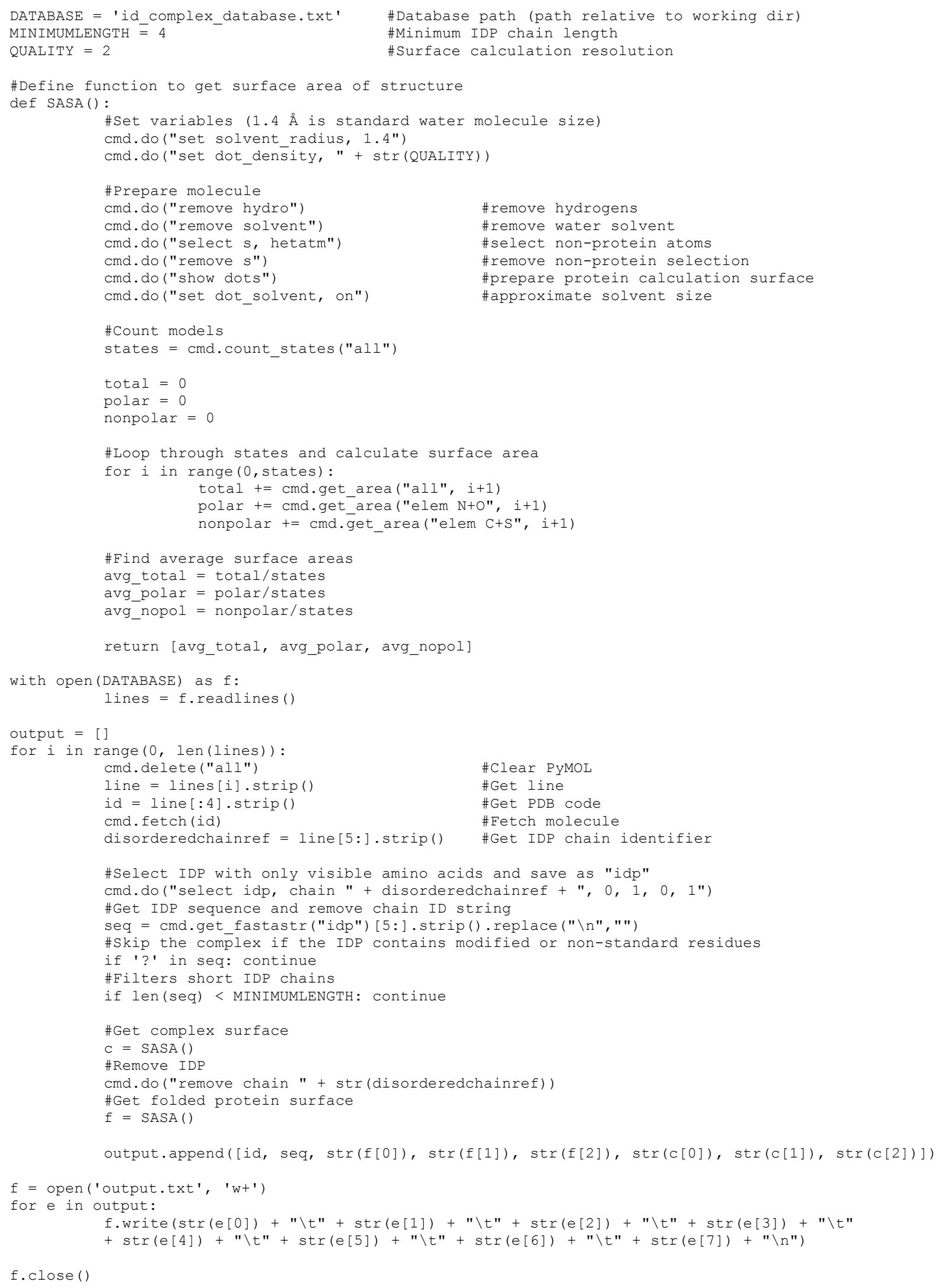




\section{REFERENCES}

(1) Robertson, A. D.; Murphy, K. P. Protein Structure and the Energetics of Protein Stability. Chem. Rev. 1997, 97 (5), 1251-1268. https://doi.org/10.1021/cr960383c.

(2) Myers, J. K.; Nick Pace, C.; Martin Scholtz, J. Denaturant m Values and Heat Capacity Changes: Relation to Changes in Accessible Surface Areas of Protein Unfolding. Protein Sci. 1995, 4 (10), 2138-2148. https://doi.org/10.1002/pro.5560041020.

(3) Livingstone, J. R.; Spolar, R. S.; Record, M. T. Contribution to the Thermodynamics of Protein Folding from the Reduction in Water-Accessible Nonpolar Surface Area. Biochemistry 1991, 30 (17), 4237-4244. https://doi.org/10.1021/bi00231a019.

(4) Makhatadze, G. I.; Privalov, P. L. Energetics of Protein Structure. In Advances in Protein Chemistry; 1995; Vol. 47, pp 307425. https://doi.org/10.1016/S0065-3233(08)60548-3.

(5) Makhatadze, G. I.; Privalov, P. L. Energetics of Interactions of Aromatic Hydrocarbons with Water. Biophys. Chem. 1994, 50 (3), 285-291. https://doi.org/10.1016/0301-4622(93)E0096-N.

(6) Baldwin, R. L. Temperature Dependence of the Hydrophobic Interaction in Protein Folding. Proc. Natl. Acad. Sci. 1986, 83 (21), 8069-8072. https://doi.org/10.1073/pnas.83.21.8069.

(7) Murphy, K. P.; Freire, E. Thermodynamics of Structural Stability and Cooperative Folding Behavior in Proteins. Adv. Protein Chem. 1992, 43, 313-361. https://doi.org/10.1016/s0065-3233(08)60556-2.

(8) Spolar, R.; Record, M. Coupling of Local Folding to Site-Specific Binding of Proteins to DNA. Science (80-. ). 1994, 263 (5148), 777-784. https://doi.org/10.1126/science.8303294.

(9) Lacy, E. R.; Filippov, I.; Lewis, W. S.; Otieno, S.; Xiao, L.; Weiss, S.; Hengst, L.; Kriwacki, R. W. P27 Binds Cyclin-CDK Complexes through a Sequential Mechanism Involving Binding-Induced Protein Folding. Nat. Struct. Mol. Biol. 2004, 11 (4), 358-364. https://doi.org/10.1038/nsmb746.

(10) Cervantes, C. F.; Bergqvist, S.; Kjaergaard, M.; Kroon, G.; Sue, S.-C.; Dyson, H. J.; Komives, E. A. The RelA Nuclear Localization Signal Folds upon Binding to IxBa. J. Mol. Biol. 2011, 405 (3), $754-764$. https://doi.org/10.1016/j.jmb.2010.10.055.

(11) Lawrence, C. W.; Kumar, S.; Noid, W. G.; Showalter, S. A. Role of Ordered Proteins in the Folding-Upon-Binding of Intrinsically Disordered Proteins. J. Phys. Chem. Lett. 2014, 5 (5), 833-838. https://doi.org/10.1021/jz402729x.

(12) Jemth, P.; Karlsson, E.; Vögeli, B.; Guzovsky, B.; Andersson, E.; Hultqvist, G.; Dogan, J.; Güntert, P.; Riek, R.; Chi, C. N. Structure and Dynamics Conspire in the Evolution of Affinity between Intrinsically Disordered Proteins. Sci. Adv. 2018, 4 (10). https://doi.org/10.1126/sciadv.aau4130.

(13) Ramírez, J.; Recht, R.; Charbonnier, S.; Ennifar, E.; Atkinson, R. A.; Travé, G.; Nominé, Y.; Kieffer, B. Disorder-to-Order Transition of MAGI-1 PDZ1 C-Terminal Extension upon Peptide Binding: Thermodynamic and Dynamic Insights. Biochemistry 2015, 54 (6), 1327-1337. https://doi.org/10.1021/bi500845j.

(14) Berjanskii, M. V.; Wishart, D. S. A Simple Method to Predict Protein Flexibility Using Secondary Chemical Shifts. J. Am. Chem. Soc. 2005, 127 (43), 14970-14971. https://doi.org/10.1021/ja054842f.

(15) Bugge, K.; Staby, L.; Kemplen, K. R.; O’Shea, C.; Bendsen, S. K.; Jensen, M. K.; Olsen, J. G.; Skriver, K.; Kragelund, B. B. Structure of Radical-Induced Cell Death1 Hub Domain Reveals a Common A $\alpha$-Scaffold for Disorder in Transcriptional Networks. Structure 2018, 26 (5), 734-746.e7. https://doi.org/10.1016/j.str.2018.03.013.

(16) Shrake, A.; Rupley, J. A. Environment and Exposure to Solvent of Protein Atoms. Lysozyme and Insulin. J. Mol. Biol. 1973, 79 (2), 361-371. https://doi.org/10.1016/0022-2836(73)90011-9. 